\title{
50 éves az Agrokémia és Talajtan
}

Az AGROKÉMIA ÉS TALAJTAN jelen számával 50. évfolyamába lép. Hazai tudományos folyóirataink között sajnos elég ritka jubileumhoz értünk. Rövid történeti áttekintésünkkel ezúton köszöntjük az AGROKÉMIA ÉS TALAJTAN 50 évfolyamának olvasótáborát, szerzőit, lektorait, szerkesztőbizottsági tagjait és közremüködőit. Köszönet az érdeklődésért és munkáért mindannyiuknak!

Az AGROKÉMIA ÉS TALAJTAN a talajtan, agrokémia, talajbiológia és talajbiokémia szakterületek tudományos folyóirata. Publikációs misszióját kezdettől fogva és gyakorlatilag töretlenül három alapvető célkitüzés határozta és határozza meg:

- nemzetközi színvonalú fórum a szakterület magyar tudományos eredményeinek széles körü hazai és nemzetközi megismertetésére;

- a magyar szaknyelv ápolása;

- a szakterület nemzetközi trendjeinek, föbb eredményeinek, fontosabb történéseinek folyamatos figyelemmel kísérése.

Hogy e célokat az 50 év során mikor, milyen eredményességgel és hatékonysággal sikerült megvalósítani, azt az olvasótábornak kell eldöntenie. A publikációs tevékenység nyilvánvalóan nem volt és nem is lehetett egyenletes, $\mathrm{s}$ folyamatosan kiegyensúlyozott. De talán így is sikerült szerény eszközeinkkel, de nagy szakmai lelkesedésünkkel eredményesen hozzájárulnunk a magyar talajtani, agrokémiai és talajbiológiai tudomány fejlődéséhez, hazai és nemzetközi elismertségéhez.

Az AGROKÉMIA ÉS TALAJTAN megszületése nem volt elözmények nélküli. Az 1949 nyarán megalakuló önálló Agrokémiai Intézet ugyanis rögtön felismerte egy tudományos folyóirat megjelentetésének szükségességét. Annál is inkább, mivel a talajtan-agrokémia-talajbiológiai szakterületnek addig nem volt önálló tudományos folyóirata. Kutatási eredményeit a Földművelésügyi Minisztérium kiadásában megjelenő „Kísérletügyi Közleményekben”, „Mezőgazdasági Kutatásokban”, „Öntözésügyi Közleményekben” és más szakfolyóiratokban, valamint az Agrokémiai Kutató Intézet Évkönyvében kap(hat)tak nyilvánosságot. Az Intézet már 1949 augusztusában megjelentette a „Talajvizsgálat" címü sokszorosított kiadvány továbbfejlesztett változatát „Agrokémia” címmel. A tartalmas és színvonalas kiadvány iránti élénk érdeklődés és erősödő 
tudományos igény tette lehetővé azután, hogy 1951 novemberében megjelenhetett az AGROKÉMIA ÉS TALAJTAN 1. száma, 1952-ben pedig 1. évfolyamának további számai.

A folyóirat első föszerkesztője (felelős szerkesztője) Páter Károly, az Intézet akkori igazgatója, technikai szerkesztője pedig Walger János volt. Páter Károlytól 1960-ban Szabolcs István vette át a föszerkesztői feladatokat, s látta el több mint 35 éven keresztül, 1997-ben bekövetkezett haláláig. 1970 elején Walger Jánostól Várallyay György vette át a szerkesztői munkát, s ö lett Szabolcs István halála után a folyóirat föszerkesztője. Füleky György (1981-től 1983-ig) és Murányi Attila (1984-től 1988-ig) folytatták a technikai szerkesztői munkát.

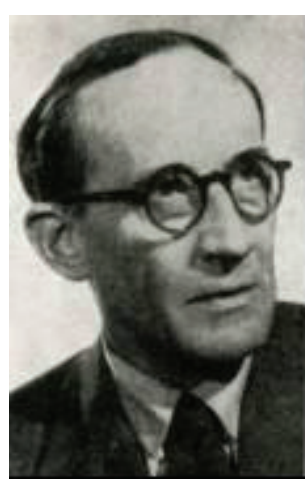

Páter Károly

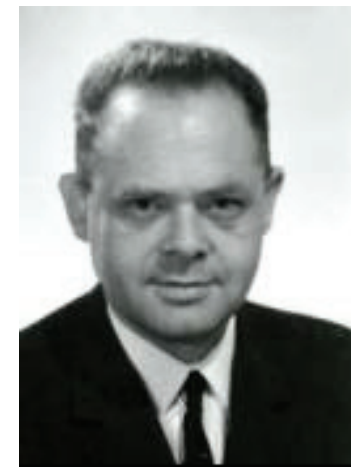

Szabolcs István

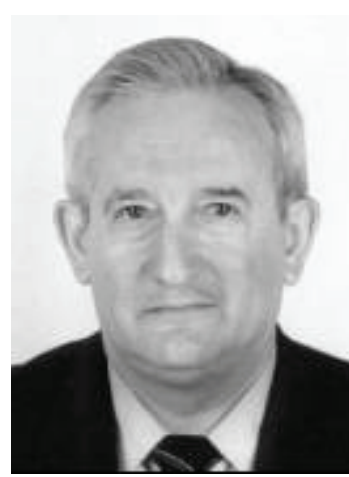

Várallyay György

Az 1. kötet Szerkesztőbizottságának tagjai: Ballenegger Róbert, di Gléria János, Fekete Zoltán, Győrffy Barna, Hegedűs István, Kúthy Sándor, Márkus László, Prettenhoffer Imre, Sarkadi János és Stefanovits Pál voltak. A Szerkesztőbizottság személyi összetétele többször változott és folyamatosan bővült. Abban az MTA Talajtani és Agrokémiai Kutató Intézet (MTA TAKI) munkatársain kívül mindig helyet kaptak a szakterületet müvelő tudományos intézetek és egyetemi tanszékek képviselöi is.

1961-ben (10. kötet) a folyóirat Szerkesztőbizottsága az alábbi összetételben múködött: Ballenegger Róbert, di Gléria János, Gerei László, Páter Károly, Stefanovits Pál, Szegi József.

1976-ban (25. kötet) a Szerkesztőbizottság munkájában az alábbi munkatársak vettek részt: Fekete Zoltán, Gerei László, Győrffy Béla, Klimes-Szmik Andor, Láng István, Latkovics Györgyné, Lőrincz József, Pántos György, Sarkadi János, Sipos Sándor, Stefanovits Pál, Szegi József.

A jelenlegi Szerkesztőbizottság tagjait fényképen mutatjuk be. 
AGROKÉMIA ÉS TALAJTAN Tom. 50. (2001) No. 1-2. 3
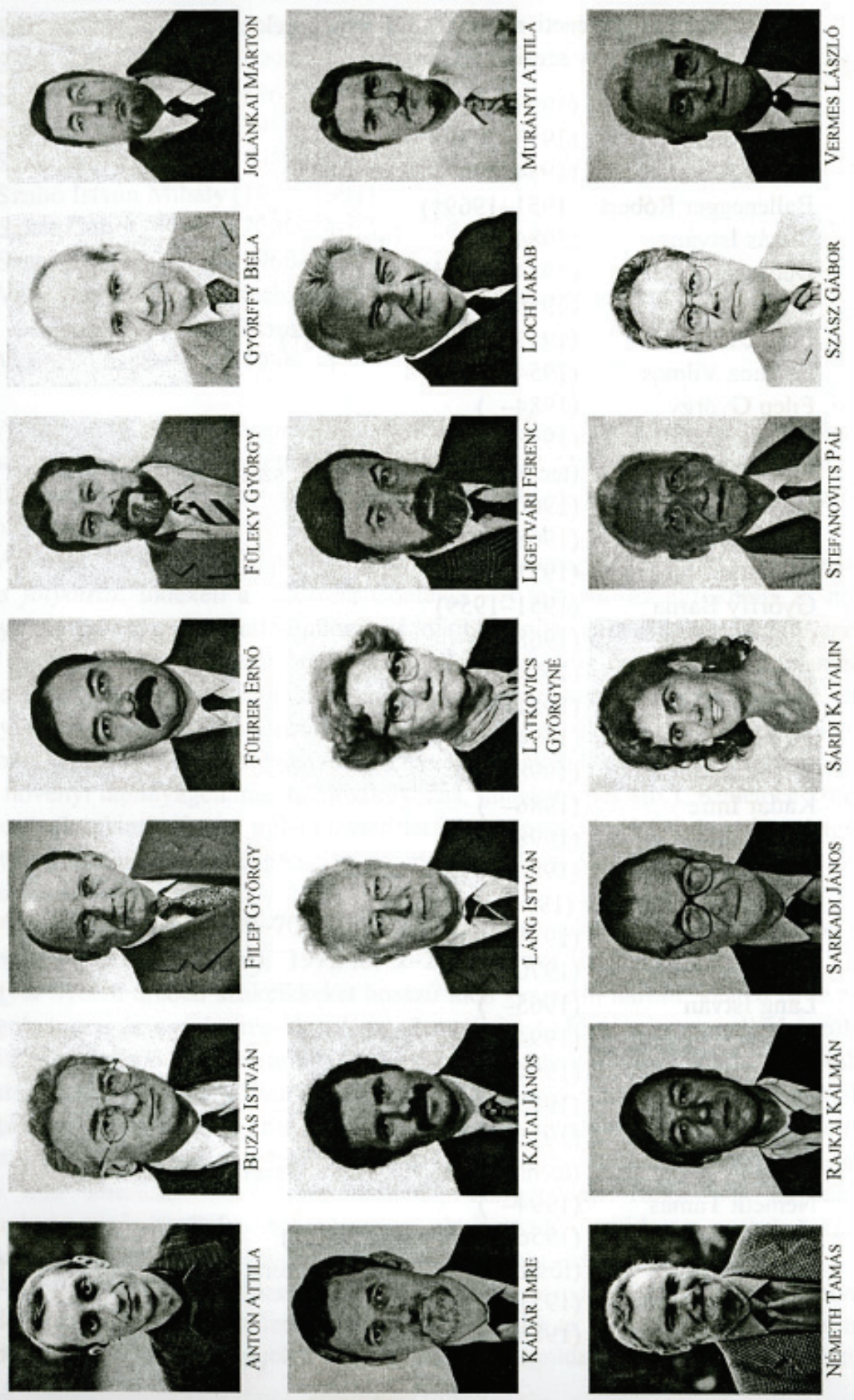
Talán tudománytörténeti szempontból sem érdektelen a Szerkesztőbizottság valamennyi tagjának név szerinti felsorolása:

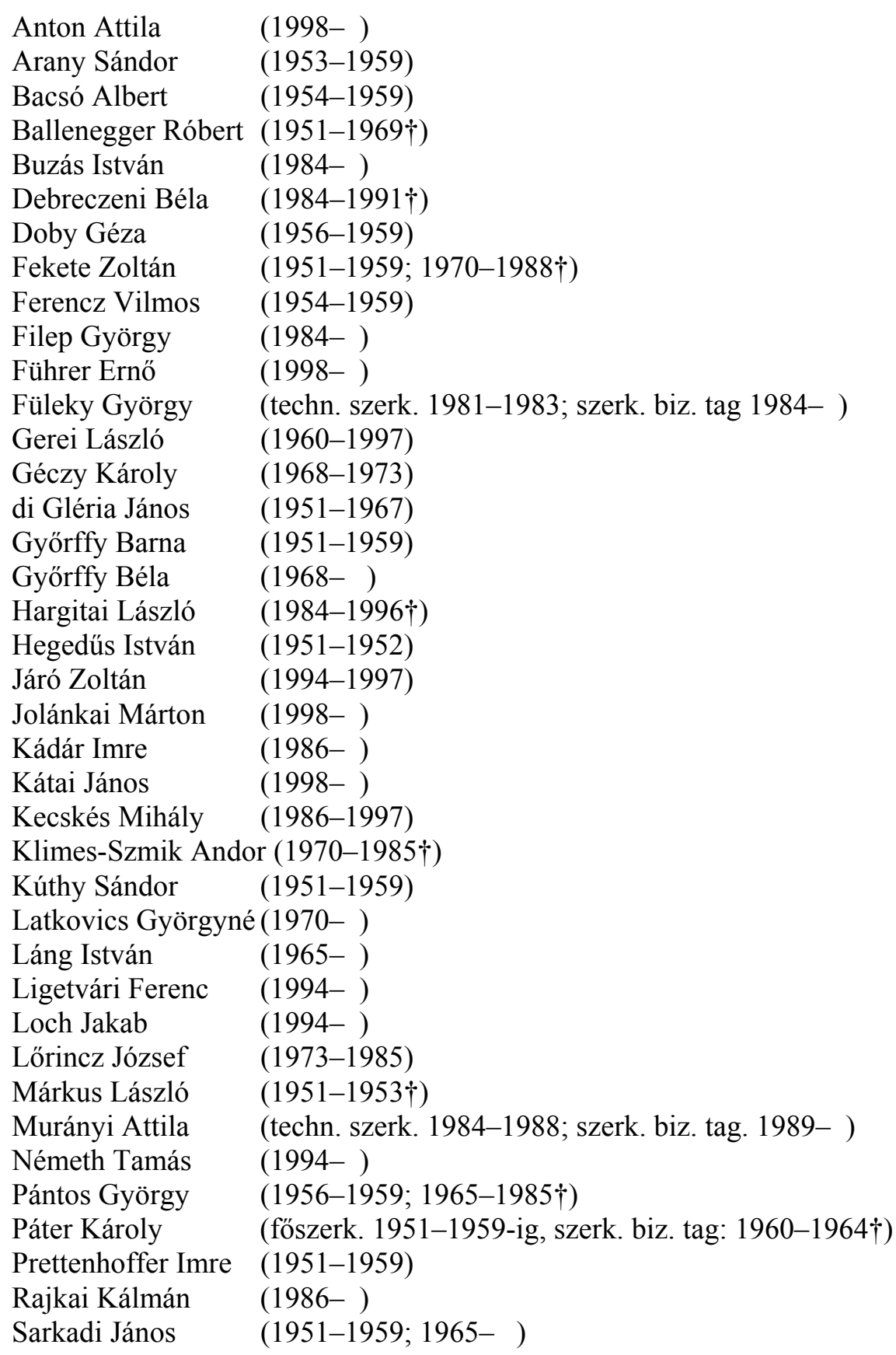


AGROKÉMIA ÉS TALAJTAN Tom. 50. (2001) No. 1-2.

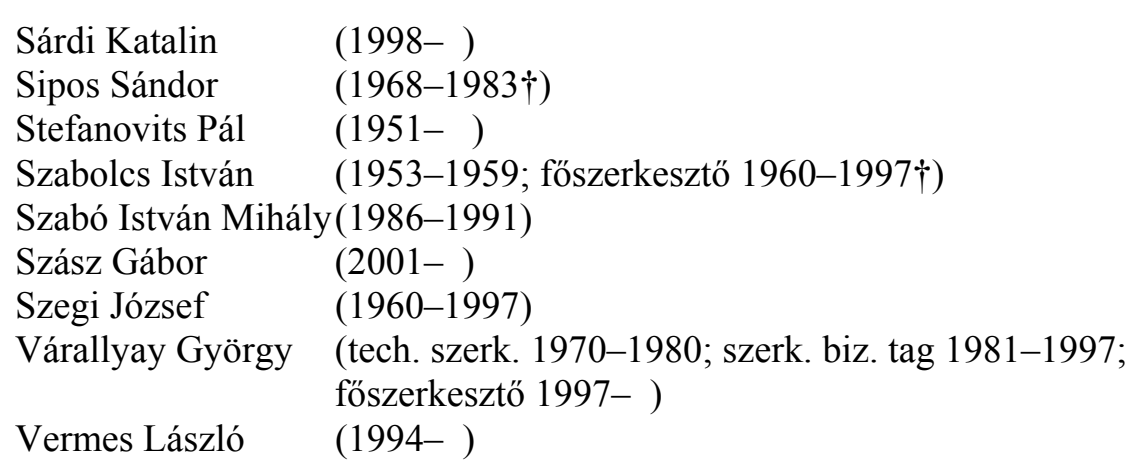

A folyóirat megindításában és szerkesztési koncepciójának kialakításában - haláláig - megkülönböztetett jelentőségü szerepet vállalt Ballenegger Róbert. Stefanovits Pál pedig 1951 óta folyamatosan, aktívan részt vesz a Szerkesztőbizottság munkájában.

Az AGROKÉMIA ÉS TALAJTAN magyar nyelven megjelenő, lektorált tudományos folyóirat. Indexeli a „Current Contents”. A talajtan, az agrokémia és növénytáplálás, valamint a talajbiológia és talajbiokémia szakterületeken közöl eredeti tudományos közleményeket, Szemle rovatában pedig összefoglaló és elemző témaismertetéseket; beszámolókat hazai és nemzetközi rendezvényekröl; és könyvismertetéseket. Vitarovatában helyt ad egy-egy aktuális tudományos kérdésben képviselt eltérő véleményeknek, polémiáknak (p1. talajjavítás, talajmüvelés, növényi tápanyagellátás, talajosztályozás, talajértékelés stb.). Kellemes kötelességének tekinti a hazai tudományterület jeles képviselőinek jubileumi születésnapjairól történő megemlékezéseket, szomorú kötelességének pedig az elhunytakról szóló nekrológokat.

A folyóirat évente 600-700 oldal terjedelemben jelenik meg, indulásakor 4 számban (negyedévenként), 1972-től 2-2 összevont számban, félévenként. A magyar nyelvü eredeti szakcikkeket hosszú időn keresztül három, idegen nyelven [angol, orosz és egy harmadik világnyelven (német, francia, spanyol)] készülö rövid összefoglaló egészítette ki, amelyek a táblázat- és ábrafeliratokat is tartalmazták. Ezzel nagymértékben elősegítve a közlemények tudományos tartalmának megértését idegen nyelvü érdeklődők számára is; s megkönnyítve a cikkek gyors referálását nagy nemzetközi referáló folyóiratokban [Soils and Fertilizers, Irrigation and Drainage (CAB International, Harpenden); Referátnüj Zsurnal, Moszkva; stb.]. Később - föként anyagi okok miatt - az idegen nyelvü összefoglalók csak két nyelven (angol, német) jelentek meg, jelenleg csupán angolul.

Az 50 év során 139 füzetben, mintegy 1500 magyar és 400 idegen nyelvü eredeti szakcikk, 660 szemlecikk, 110 vitarovat cikk és 70 egyéb cikk, összesen több mint 2700 közlemény jelent meg 27 ezer szövegoldalon. A megjelent ere- 


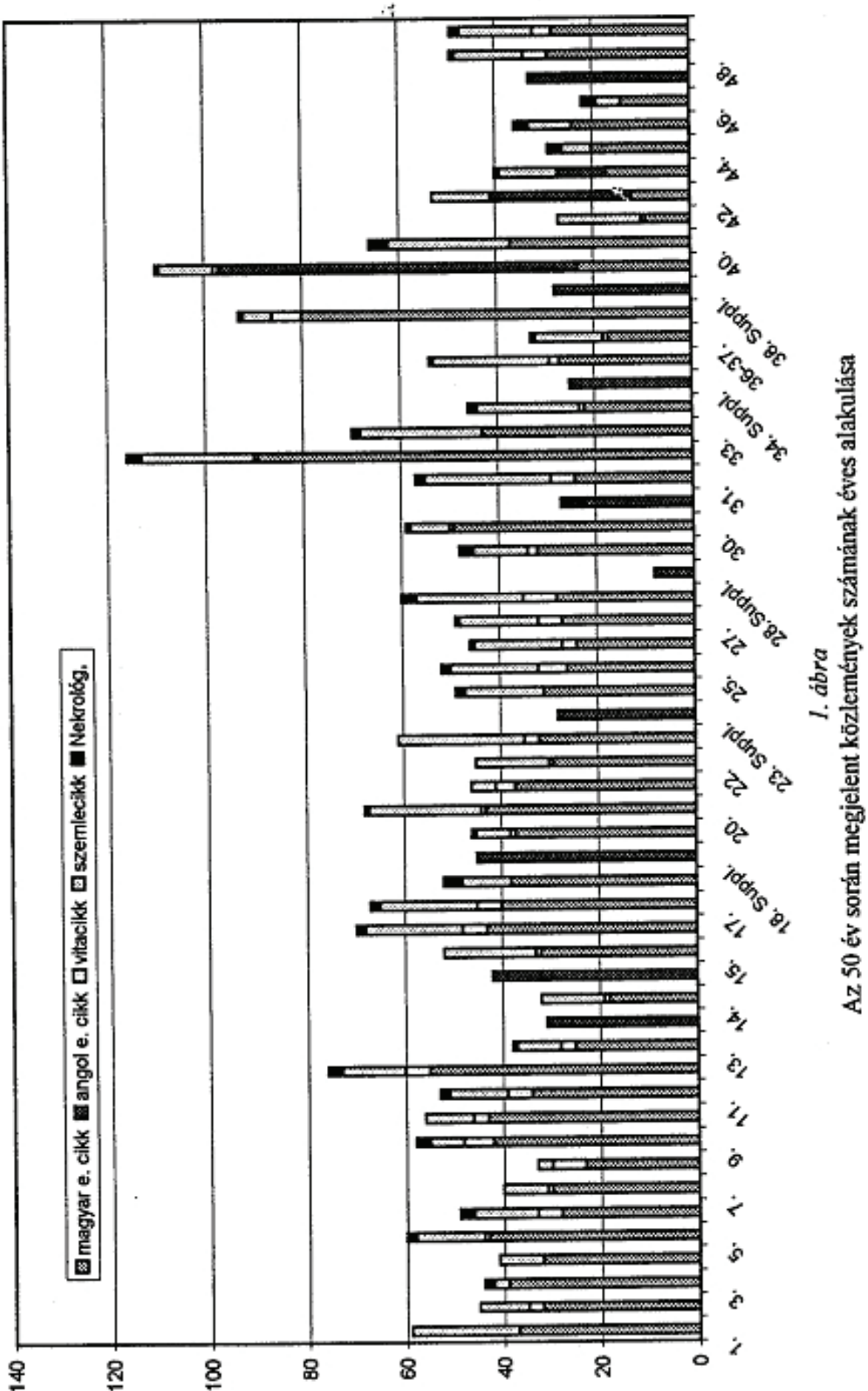


deti tudományos közlemények, szemlecikkek, vitacikkek és egyéb közlemények számának éves alakulását mutatja be az 1. ábra.

Hazai szerzőinken kívül folyamatosan publikáltak folyóiratunkban külföldi szerzők is, összesen a világ mintegy 40 országából. Köztük voltak a talajtani tudomány nemzetközi hírü jelesei; a szomszédos országok magyar szakemberei; a hazánkban végzett vagy tudományos fokozatot szerzett, ill. magyar kutatási együttműködésekben résztvevő kollegák (elsősorban a szomszédos és a fejlődő országokból).

A magyar talajtani tudomány eredményeinek széles körü nemzetközi megismertetése az 50 év során egyre nagyobb jelentőségüvé vált. Az ez irányú kihívásra nem a folyóirat magyar nyelvü közlésének megszüntetésével reagáltunk, hanem időszakosan megjelenö idegen (elsősorban angol) nyelvü kötetek megjelentetésével. A megjelent Supplementumokat, ill. idegen nyelvü köteteket érdemes tételesen is felsorolni.

1. 1964. Tom. 13. Reports of the Hungarian Soil Scientists to the VIII. International Congress of Soil Science. $272 \mathrm{pp}$.

2. 1965. Tom. 14. Proceedings of the Symposium on Sodic Soils, Budapest, 1964. $480 \mathrm{pp}$.

3. 1968. Tom. 17. Különböző hazai és külföldi szerzők angol nyelvü dolgozatai. $145 \mathrm{pp}$.

4. 1969. Tom. 18. Symposium on the Reclamation of Sodic and Soda-Saline Soils, Yerevan. $488 \mathrm{pp}$.

5. 1974. Tom. 23. Prof. A. A. J. de 'Sigmond, 1873-1939. 240 pp.

6. 1979. Tom. 28. Modelling of Soil Salinization and Alkalization. (Eds.: V. A. Kovda \& I. Szabolcs) 208 pp.

7. 1981. Tom. 30. Proceedings of the Hungarian-Indian Seminar on Salt Affected Soils, Budapest, 1981. $256 \mathrm{pp}$.

8. 1985. Tom. 34. Proceedings of the Hungarian-British Joint Seminar. Session B. Soil Fertility, Budapest, 7-13 April, 1984; Proceedings of the Seminar on Technologies for Sustainable Agriculture, 10 September 1984. $212 \mathrm{pp}$.

9. 1989. Tom. 38. No. 3-4. Proceedings of the Hungarian-Polish Seminar on Soil Water Problems (Budapest, 1-6 June, 1987); Proceedings of the Hungarian-Swedish Seminar on Soil Mapping (Budapest, 4-11 June, 1988). 517-840.

10.1990. Tom. 39. No. 3-4. Soil Biology and the Conservation of the Biosphere. Proceedings of the 10th International Symposium on Soil Biology, Keszthely, 1989. 269-608.

11.1992. Tom. 41. No. 1-2. Workshop über die „Auswirkung Luftbürtiger Stickstoffeinträge in Waldökosysteme”, Budafa, August, 1991. 3-102. 
12.1993. Tom. 42. No. 1-2. Posters, Symposium on Soil Resilience and Sustainable Land Use, Budapest, 1992. 1-220.

13.1994. Tom. 43. No. 1-2. Hungarian contributions to the 15 th International Congress of Soil Science, Acapulco, Mexico, 10-16 July, 1994. 1-240.

14.1994. Tom. 43. No. 3-4. British-Hungarian Seminar on Sustainable Land Use in Long-term Field Experiments, Debrecen, 14-15 February, 1994. $245-356$.

15.1998. Tom. 47. No. 1-4. Hungarian contributions to the 16th International Congress of Soil Science. 1-328.

A felsorolásból is kitünik, hogy a Supplementumok, ill. idegen nyelvü kötetek különböző müfajt képviseltek. Volt köztük válogatott közleményeket tartalmazó gyüjteményes kötet (3.), emlékkötet (5.), könyv jellegủ kiadvány (6.), bilaterális munkaértekezletek anyagát tartalmazó kötet (7., 8., 9., 14.), nemzetközi rendezvények anyagát összefoglaló kiadvány (2., 4., 8., 10., 11., 12.), valamint a Nemzetközi Talajtani Társaság kongresszusaira beküldött magyar dolgozatok kiadványa (1., 13., 15.). Ez utóbbiak minden kongresszuson átütő sikert arattak, s nagyon jól szolgálták a magyar talajtani-agrokémiai-talajbiológiai tudomány legújabb eredményeinek széles körü, gyors megismertetését. A hagyományt a jövőben is fenn kívánjuk tartani, s 51. kötetünk egyik számát angol nyelven jelentetjük meg a Nemzetközi Talajtani Társaság (ICSU tagszervezetté válása óta Nemzetközi Talajtani Unió) 17. Kongresszusára (Bangkok, 2002).

A 60-as évek végén és a 70-es évek elején jelentkező gyakorlati igények kielégítésére „Agrokémia és Talajtan Kiskönyvtára” sorozatot indítottunk be az Intézet kutatási eredményeinek gyakorlati elterjesztése céljából. Ennek kötetei egy-egy speciális témában jelentek meg. Anyagi okok miatt sajnos csak három Kiskönyvtár füzet jelent meg:

- 1969. Sarkadi János, Latkovics Györgyné és Máté Ferenc: A karbamid, mint mütrágya. $40 \mathrm{pp}$.

- 1971. Manninger Ernő és Bakondiné Zámory Éva: Pillangósvirágú növények Rhizobium-oltása. $47 \mathrm{pp}$.

- 1972. Latkovics Györgyné, Máté Ferenc és Sarkadi János: A kalciumnitrát mütrágya. $39 \mathrm{pp}$.

Az AGROKÉMIA ÉS TALAJTAN mindvégig a Magyar Tudományos Akadémia Talajtani és Agrokémiai Kutató Intézetének (MTA TAKI) kiadványaként jelent meg. 1972-től 1997-ig a Magyar Agrártudományi Egyesület Talajtani Társaságának, 1999-től az MTA Agrártudományok Osztályának támogatásával, az Akadémiai Kiadó gondozásában. A folyóirat megjelenési példányszáma 1952ben 500-zal indult, ami a 70-es évekre 1150-re emelkedett, jelenleg 500. A hazai és külföldi előfizetők száma 100. Az előfizetéseken és intézetkiadvány- 


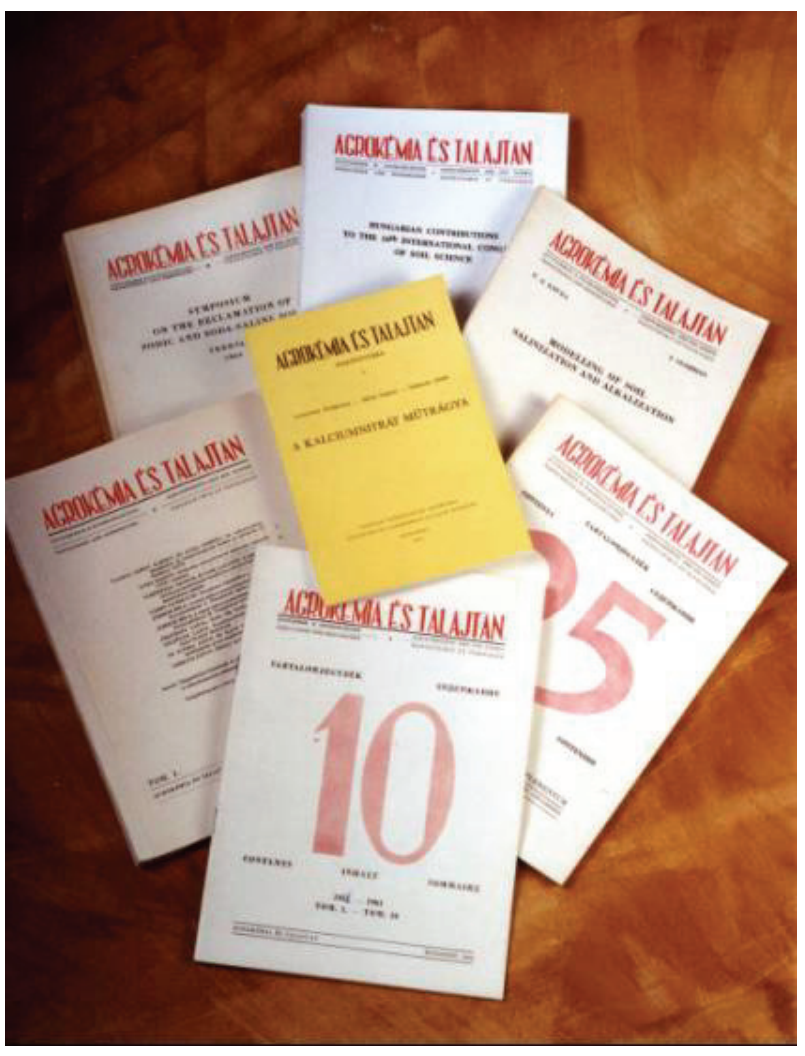

2. ábra

Néhány kiadványból összeállított válogatás

ként történő bel- és külföldi ajándékozásokon túlmenően a folyóirat cserekapcsolatai is jelentősek. A külföldi cserekapcsolatok száma a 70-es években 300 fölé emelkedett, ami jelentős devizakiváltó tényezővé vált, s nagymértékben hozzájárult az MTA TAKI folyóirat-beszerzésének zavartalan fenntartásához, a folyóiratok számának és árának növekedése és a súlyos devizakorlátozások időszakában is. Azóta cserekapcsolataink mintegy 150-re estek vissza, de így is komoly kapcsolatfenntartó jelentőségük van.

A félévszázados jubileumi értékelésnél a fentiekben röviden összefoglalt eredményeket kell összevetni küldetés-nyilatkozatunkban megfogalmazott célkitüzéseinkkel. Úgy vélem, ez az összevetés nem ad okot szégyenkezésre. A folyóirat következetesen érvényesítette alapkoncepcióját:

- a talajtan-agrokémia-talajbiológia szakterület magyar tudományos eredményeinek széles körü hazai és nemzetközi megismertetését; 
- az AGROKÉMIA ÉS TALAJTAN olvasótáborának folyamatos tájékoztatását a szakterület külföldi elért új tudományos eredményeiről, eseményeiről;

- kapcsolattartást a társtudományokkal; különbözö szintű szakoktatással, valamint a kutatási eredményeket (remélhetőleg eredményesen) hasznosító intézményekkel, üzemekkel, gazdaságokkal.

Így tudtunk a tudás-transzfer hatékony eszközévé válni, egyaránt segítve a szakterület problémáinak megoldását, valamint a kutatási feladatok racionális elvégzését. Munkánk nem lehetett volna eredményes olvasótáborunk érdeklődése; szerzőink aktivitása; szerkesztőbizottságunk, lektoraink, fordítóink és technikai munkatársaink felelősségteljes, lelkes és pontos munkája nélkül. Kellett mindehhez a Magyar Tudományos Akadémia és az MTA Talajtani és Agrokémiai Kutató Intézete elvi és anyagi támogatása, s a talajtani-agrokémiaitalajbiológiai szakember-társadalom segíteni kész hozzáállása. Ezeket köszönjük! Számítunk rá a jövőben is, a folyóirat második ötven esztendejében!

VÁRALLYAY GYÖRGY 